regeneration-rate, it is obvious that fœtal hæmoglobin has been formed in extra-uterine life. Cases with an indiscriminate destruction of patient's and donor's cells show that there is no relationship whatever to the type of hæmoglobin present in the red blood corpuscles. In full agreement with these findings are the results obtained by Mollison', who studied the survival of transfused erythrocytes in hæmolytic disease of the new-born by the method of differential agglutination. In almost all cases where $R h$-positive red blood cells have been transfused they were eliminated within ten days. The destruction of erythrocytes in hæmolytic disease of the new-born depends on their sensitization by $R h$ antibodies and shows no relationship to the chemical constitution of the globin component of their chromoprotein.

Department of Pathology,

The Children's Hospital, Birmingham.

1 Jonxis, J. H. P., Nature, 161, 850 (1948).

2 Baar, H. S., and Hickmans, E. M., J. Physiol., 100, Proc. 3 (1941),

${ }^{3}$ Baar, H. S., and Lloyd, T. W., Arch. Dis. Child., 18, 124 (1943).

- Haurowitz, F., Hoppe-Seylers $Z ., 183,78$ (1929).

' Mollison, P. L., Arch. Dis. Child., 18, 161 (1943).

\section{Carbonic Anhydrase in Arenicola marina}

Several years ago, Brinkman and his collaborators reported that carbonic anhydrase is present in the blood of Arenicola ${ }^{1}$. This observation was confirmed by Florkin ${ }^{2}$. Recently, through the kindness of Prof. H. Munro Fox, I have had an opportunity of studying the distribution of the enzyme in this annelid in more detail than was done in these two papers, and some interesting points have come to light.

The determinations of enzyme activity were made by the 'boat' method of Meldrum and Roughton ${ }^{3}$, precautions being taken to ensure that diffusion did not constitute a limiting factor. All the experiments were carried out at $0^{\circ} \mathrm{C}$., the Meldrum - Roughton unit of activity being calculated for that temperature. Tissues were cut into small pieces, washed with several changes of sea water and then weighed. After being ground with a little sand, they were extracted for one hour at room temperature with distilled water in the proportion of $1 \mathrm{ml}$. to each $25 \mathrm{mgm}$. of tissue. The catalytic effect of the tissue extracts was always compared with the activity of blood diluted to give the same final hæmoglobin concentration. Hence any errors due to traces of blood remaining in the tissues were reduced to a minimum. Hæmoglobin was determined directly with a Hilger-Nutting spectrophotometer.

Table 1 gives the figures obtained for blood samples taken from five individuals, together with figures for human blood (A.M. C.) to serve as a comparison. It will be seen that the mean activity of Arenicola blood is about the same as that of human blood, although there is considerable individual variation.

\begin{tabular}{|c|c|c|}
\hline $\begin{array}{c}\text { Enzyme } \\
\text { (units per c.mm.) }\end{array}$ & $\begin{array}{c}\text { Hæmoglobin } \\
(\mathrm{gm} . \%)\end{array}$ & $\begin{array}{l}\text { Activity : } \\
\text { hæmozlobin }\end{array}$ \\
\hline $\begin{array}{l}4 \cdot 0 \\
3 \cdot 6 \\
4 \cdot 5 \\
3 \cdot 4 \\
2 \cdot 6\end{array}$ & $\begin{array}{l}2 \cdot 9 \\
3 \cdot 5 \\
4 \cdot 1 \\
2 \cdot 6 \\
1 \cdot 8\end{array}$ & $\begin{array}{l}1 \cdot 38 \\
1 \cdot 03 \\
1 \cdot 10 \\
1 \cdot 31 \\
1 \cdot 44\end{array}$ \\
\hline Mean : $3 \cdot 6$ & Mean : $3 \cdot 0$ & Mean : $1 \cdot 25$ \\
\hline 3.7 (A. M. C.) & $15 \cdot 3$ & 0.024 \\
\hline
\end{tabular}

The ratio of enzyme activity to hæmoglobin concentration, calculated as units of enzyme per cubic millimetre of blood and grams of hæmoglobin per hundred c.c., is much higher in Arenicola than in human blood and tends to be fairly constant. The presence of such a large amount of carbonic anhydrase is of considerable importance, for Arenicola blood, like that of most annelids, contains very few corpuscles. Of four samples of blood centrifuged for thirty minutes at 3,200 r.p.m., only one showed any signs of a slight deposit of cellular material. Thus the enzyme must be free in solution, an exception to the generalization that carbonic anhydrase is never found outside cells 4 .

The enzyme is also present in appreciable amounts in many of the tissues of Arenicola (Table 2) but is absent from the cœlomic fluid, as was noted by Florkin.

\begin{tabular}{|c|c|}
\hline Tissue & $\begin{array}{l}\text { Units of enzyme } \\
\text { per } 50 \mathrm{mgm} \text {. wet weight }\end{array}$ \\
\hline Esophageal pouches & $71-110$ \\
\hline Chlorogenous tissue of stomach & $15-38$ \\
\hline Gills & $5-15$ \\
\hline Esophagus & $6-14$ \\
\hline Nephridia & $3-12$ \\
\hline Intestine & $1-4$ \\
\hline Ep dermis & $1-3$ \\
\hline Muscles & Traces \\
\hline Proboscis & Traces \\
\hline Nerve cord & $\mathrm{Nil}$ \\
\hline Cœlomic fluid & Nil \\
\hline
\end{tabular}

Of all the tissues examined, the œsophageal pouches showed the highest concentration of carbonic anhydrase. Although these diverticula have a very rich blood supply from several large sinuses situated beneath the inner epithelial lining, it seems rather improbable that they play an important part in the direct elimination of respiratory carbon dioxide from an animal so well equipped with external gills as Arenicola. On the other hand, it is difficult to see what other function they could have. The secretion is only slightly acid ( $p H$ about $6 \cdot 4$ ), so the glands can scarcely be similar to the gastric glands of vertebrates. It might be worth while considering whether the pouches represent a primitive respiratory organ which was of importance in annelids lacking external gills. In this connexion it is interesting to recall the work of Eisig $^{5}$ on some of the smaller polychætes. He made a careful study of the œsophageal diverticula in syllids and hesionids and concluded that they act as reservoirs of water and air, from which oxygen can be obtained when the supply from the external medium is insufficient to meet the organism's requirements. Eisig compared the pouches with the swim bladder of a fish. It would be interesting to examine the catalytic activity of the tissues of Arenicola assimilis, a form which possesses several pairs of œesophageal pouches.

This investigation is being carried out during the tenure of an 1851 Exhibition Science Research Scholarship. My thanks are due to Prof. D. Keilin for suggesting the problem and for his interest in its progress.

Molteno Institute,
Cambridge.

A. M. Clark

\section{April 22.} ${ }^{1}$ Brinkman, Margaria, Meldrum and Roughton, J. Physiol., 75, 3P

2 Florkin, Arch. Int. Physiol., 40, 283 (1935).

s Meldrum and Roughton, $J$, Physiol., 80, 113 (1934).

- Van Goor, Enzymologia, 8, 113 (1940).

s Eisig, Mitt. Zool. Stat. Neapel., 2, 255 (1881). 